TECHNO

Vol.19, No.2, Oktober 2018, Hal. 113 123

P-ISSN: 1410-8607, E-ISSN: 2579-9096

\title{
Analisa Model Matematik Arus Sejajar Pantai Pada Groin Seri Permeable
}

\author{
Adi Surya Pria Pranata ${ }^{1}$, Novi Andhi Setyo Purwono ${ }^{2}$, Ary Sismiani ${ }^{3}$ \\ ${ }^{1}$ Profesional \\ 2,3 Program Studi S1 Teknik Sipil Universitas Wijayakusuma Purwokerto
}

\section{Informasi Makalah}

Dikirim, 20 Agustus 2018

Direvisi, 31 Oktober 2018

Diterima, 31 Oktober , 2018

\section{Kata Kunci:}

Groin

arus menyusur pantai

\section{Keyword:}

Groins

longshore current

\section{INTISARI}

Penelitian ini dilakukan pengujian terhadap dua model groin, yaitu model groin permeable dan groin impermeable, dengan variasi panjang groin dan variasi jarak antar groin 50 meter, 100 meter, 150 meter dan 200 meter. Permodelan dilakukan dengan menggunakan data-data penelitian permodelan fisik oleh Chen., dkk 2003, dan digunakan sebagai masukan pada simulasi model matematik menggunakan bantuan perangkat lunak Boussinesq 2D. Hasil penelitian menunjukan adanya pengaruh model variasi panjang groin dan jarak antar groin, reduksi kecepatan arus menyusur pantai dengan ratarata reduksi sebesar 59,21 \% untuk groin permeable ganda dengan panjang groin 50 meter, panjang groin 100 meter 76,02\%, panjang groin 150 meter $79,50 \%$ dan panjang groin 200 meter 80,49\%. Reduksi kecepatan arus menyusur pantai dengan rata-rata reduksi sebesar 57,42 \% untuk groin impermeable ganda dengan panjang groin 50 meter, panjang groin 100 meter 84,61\%, panjang groin 150 meter 88,89\% dan panjang groin 200 meter $89,91 \%$. Variasi jarak antar groin dan variasi panjang groin diperoleh hasil bahwa semakin panjang groin permeable atau groin impermeable berpengaruh terhadap reduksi kecepatan arus menyusur pantai yang terjdi di daerah surf zone dengan penambahan reduksi kecepatan arus menyusur pantai yang terjadi sebesar $>20 \%$. Reduksi kecepatan arus menyusur pantai oleh groin permeable maupun groin impermeable tidak terjadi penambahan reduksi yang signifikan pada panjang groin dengan panjang melebihi daerah Surf zone dengan rata-rata penambahan reduksi sebesar $>5 \%$. kecepatan arus menyusur pantai mendekati kecepatan arus menyusur pantai pada kondisi existing pada jarak $>2,4 \mathrm{x}$ panjang groin. Dan Jarak antara groin yang terlalu dekat dibandingkan dengan panjang groin, menyebabkan pergerakan arah arus menuju ke arah laut (rip current).

\begin{abstract}
This research is the mathematical model has been made with two groins, permeable and impermeable groins, with the variation is in length and distance; 50 meters, 100 meters, 150 meters and 200 meters. A modelling has been done by using the data of physical modeling study by Chen., et al, 2003, and used as input to the simulation of mathematical models using $2 \mathrm{D}$ Boussinesq software. Results of the research showed the influence of variation model long distance between the groins, the reduction of longshore current velocity along the coast with an average $59.21 \%$ reduction for the double permeable groin with 50 meters long, $76.02 \%$ for 100 meters, $79.50 \%$ for 150 meters, $80.49 \%$ for 200 meters. The reduction of longshore current velocity along the coast are $57.42 \%$ for an impermeable groin groin double with 50 meters, $84.61 \%$ for 100 meters, $150 \%$ for 88.89 meters, and $89.91 \%$ for 200 meters. The distance variation between one groin to the other groin has a result that a longer permeable or impermeable groin affects the reduction longshore current velocity along the coast of the Surf Zone with the addition of longshore current velocity reduction occurs along the coast up to $20 \%$. Reduction of longshore current velocity along the coast by the permeable and impermeable groin Permeable and impermeable groins has not been significantly occured in the long-term groin area exceeding Surf zone with an average additional reduction up to 5\%. The longshore current velocity approaching the speed of currents along the coast for the existing conditions at a distance up to 2.4 times of length of groins. And the distance between the groins are too close if we compare to the long groins causing the current direction of movement towards the sea (rip current).
\end{abstract}


Korespondensi Penulis:

Adi Surya Pria Pranata ${ }^{1}$

Program Studi S1 Teknik Sipil

Universitas Wijayakusuma Purwokerto

Jl Raya Beji Purwokerto

Email: pranata.adi2@gmail.com

\section{PENDAHULUAN}

Perlindungan pantai terhadap abrasi akibat gelombang telah dikembangkan oleh banyak negara melalui pendekatan keilmuan teknis yang berkembang pesat. Bangunan pengaman pantai berupa groin impermeable merupakan salah satu teknologi untuk meredam daya abrasi akibat rambatan gelombang yang banyak diterapkan di Indonesia. Bangunan groin ini memiliki kelemahan yaitu daerah downstream masih mengalami abrasi, oleh sebab itu perlu dilakukan penelitian tentang efektivitas penggunaan groin permeable sebagai salah satu alternatif mengurangi abrasi pantai.

Penelitian yang di lapangan akan membutuhkan waktu yang sangat panjang dan biaya mahal, oleh karena itu dilakukan uji model fisik dengan prototipe struktur groin permeable di Laboratorium Hidraulika, Jurusan Teknik Sipil dan Lingkungan, Universitas Gadjah Mada Yogyakarta. Analisa ini masih berkendala karena pengamatan kecepatan arus pada model uji fisik hanya dapat dilakukan pada titik-titik tertentu, untuk itu selanjutnya data yang telah didapat tersebut menjadi masukan terhadap uji model matematik menggunakan bantuan perangkat lunak Boussinesq 2D untuk mengetahui kecepatan arus menyusur pantai yang tereduksi oleh struktur groin permeable dan pola arus menyusur pantai di sepanjang pantai. Keterbatasan ukuran grid model numerik yang tidak dapat mengakomodir ukuran groin permeable pada model fisik, maka pada penelitian ini menggunakan data-data sekunder dari penelitian yang digunakan oleh Chen., dkk 2003. Data-data sekunder yang digunakan adalah data batimetri, topografi, tinggi gelombang, periode gelombang dan arah datang gelombang.

\section{METODOLOGI PENELITIAN}

Penelitian dengan pembuatan model arus menyusur pantai dilakukan menggunakan data sekunder data batimetri, topografi, tinggi gelombang, periode gelombang dan arah datang gelombang dari data penelitian yang dilakukan oleh Chen,. 2003 (Gambar 4 dan Gambar 5). Pembuatan model pada penelitian ini menggunakan software SMS 10.0 modul Boussinesq 2D. Pelaksanaan penelitian menggunakan dasar pantai yang tetap (fix bed model) serta menggunakan groin kedap air (impermeable) dan tidak kedap air (permeable) dengan variasi jarak antara groin dan panjang groin seperti pada Table 1. Gambar 1 menunjukkan data kontur garis pantai dan batimetri yang digunakan dalam pembuatan model. Gambar 2 menunjukkan sistem grid yang digunakan dalam pembuatan model.

Tabel 1. Parameter uji model arus menyusur pantai dengan model Boussinesq.

\begin{tabular}{clccc} 
No. & Nama Model & Tipe groin & L & B \\
\hline 1 & A-EXISTING & - & - & - \\
\hline 2 & P 50 L50 & permeable & 50 & 50 \\
\hline 3 & P 50 L100 & permeable & 50 & 100 \\
\hline 4 & P 50 L150 & permeable & 50 & 150 \\
\hline 5 & P 50 L200 & permeable & 50 & 200 \\
\hline 6 & P 100 L50 & permeable & 100 & 50 \\
\hline 7 & P 100 L100 & permeable & 100 & 100 \\
\hline 8 & P 100 L150 & permeable & 100 & 150 \\
\hline 9 & P 100 L200 & permeable & 100 & 200 \\
\hline 10 & P 150 L50 & permeable & 150 & 50 \\
\hline 11 & P 150 L100 & permeable & 150 & 100 \\
\hline
\end{tabular}

Techno Vol.19, No. 2, Oktober 2018: $113-123$ 


\begin{tabular}{clccc}
\hline No. & Nama Model & Tipe groin & L & B \\
\hline 2 & P 150 L150 & permeable & 150 & 150 \\
\hline 13 & P 150 L200 & permeable & 150 & 200 \\
\hline 14 & P 200 L50 & permeable & 200 & 50 \\
\hline 15 & P 200 L100 & permeable & 200 & 100 \\
\hline 16 & P 200 L150 & permeable & 200 & 150 \\
\hline 17 & P 200 L200 & permeable & 200 & 200 \\
\hline 18 & I 50 L50 & impermeable & 50 & 50 \\
\hline 19 & I 50 L100 & impermeable & 50 & 100 \\
\hline 20 & I 50 L150 & impermeable & 50 & 150 \\
\hline 21 & I 50 L200 & impermeable & 50 & 200 \\
\hline 22 & I 100 L50 & impermeable & 100 & 50 \\
\hline 23 & I 100 L100 & impermeable & 100 & 100 \\
\hline 24 & I 100 L150 & impermeable & 100 & 150 \\
\hline 25 & I 100 L200 & impermeable & 100 & 200 \\
\hline 26 & I 150 L50 & impermeable & 150 & 50 \\
\hline 27 & I 150 L100 & impermeable & 150 & 100 \\
\hline 28 & I 150 L150 & impermeable & 150 & 150 \\
\hline 29 & I 150 L200 & impermeable & 150 & 200 \\
\hline 30 & I 200 L50 & impermeable & 200 & 50 \\
\hline 31 & I 200 L100 & impermeable & 200 & 100 \\
\hline 32 & I 200 L150 & impermeable & 200 & 150 \\
\hline 33 & I 200 L200 & impermeable & 200 & 200 \\
\hline & & & &
\end{tabular}

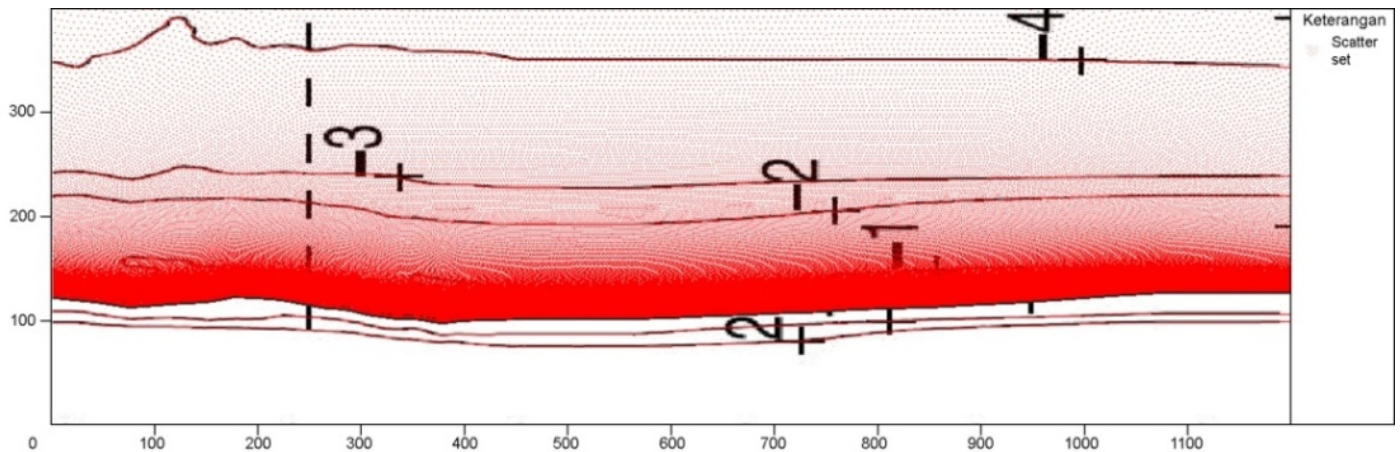

Gambar 1. Data batimetri yang digunakan dalam model numerik (sumber : Chen., 2003)

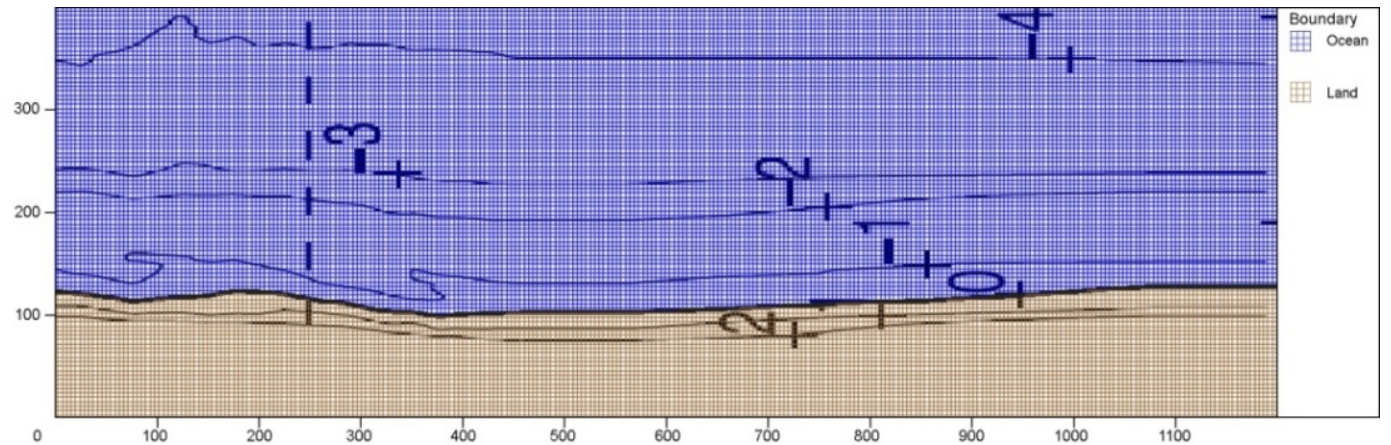

Gambar 2. Grid yang digunakan dalam model numerik (sumber : Chen., 2003) 


\section{HASIL DAN PEMBAHASAN}

\section{Verifikasi model Boussinesq}

Verifikasi model Boussinesq pada Gambar 3 dilakukan pada kondisi ekisting atau tanpa groin, dengan menggunakan data-data penelitian yang dilakukan oleh Chen., dkk 2003. Hasil ektrak kecepatan arus menyusur pantai di lokasi yang sama yaitu pada grid x 300 meter, diperoleh kecepatan maksimum 0,59 m/s, sedangkan kecepatan maksimum

pengamatan oleh Chen., dkk 2003 diperoleh kecepatan arus sebesar 1,02 m/s. Hasil perhitungan nilai mean relative error sebesar 42,66 \%, sedangkan puncak atau lokasi terjadinya kecepatan arus maksimum model terjadi pada jarak model 175 meter dan kecepatan arus maksimum pengamatan terjadi pada jarak 178 meter.

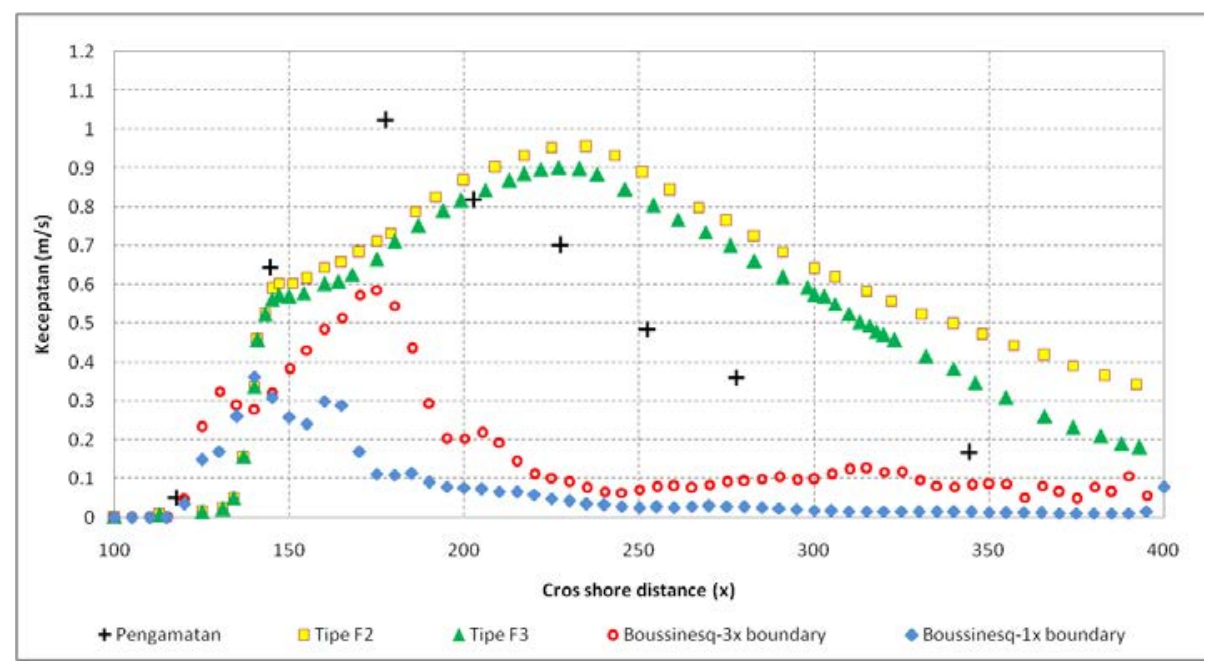

Gambar 3. Verifikasi model arus menyusur pantai (sumber : Chen., dkk 2003)

Hasil model numerik yang dilakukan oleh Chen., dkk 2003 diperoleh kecepatan maksimum untuk model tipe satu sebesar 0,95 m/s dan model tipe dua sebesar 0,90 m/s dengan lokasi terjadi kecepatan arus maksimum pada jarak 225 meter untuk model tipe F2 dan 227 meter untuk model tipe F3. Hasil ektrax kecepatan arus menyusur pantai di lokasi yang sama dengan terjadinya kecepatan arus maksimum diperoleh kecepatan arus model tipe F2 sebesar 0,73 m/s sedangkan kecepatan arus model tipe F3 sebesar 0,71 m/s, sehingga diperoleh mean relative error untuk model tipe F2 sebesar 28,46 \% dan model tipe F3 sebesar 30,53 \%.

Gambar 4 berturut-turut dari atas ke bawah menunjukkan hasil model kecepatan arus menyusur pantai oleh Chen,. Dkk 2003. Gambar kedua dari atas menunjukkan kecepatan arus menyusur pantai dengan

panjang daerah model 1200 meter, Gambar ketiga dari atas menunjukkan kecepatan arus menyusur pantai dengan panjang daerah model 3600 meter, sedangkan Gambar keempat dari atas menunjukkan hasil cros section arus menyusur pantai pada kondisi eksisting. Hasil cros section kecepatan arus secara horizontal atau menyusur pantai diperoleh bahwa rata-rata kecepatan arus pada hasil model dengan panjang daerah model tiga kali panjang daerah model oleh Chen memiliki kecepatan arus seragam di sepanjang daerah kajian, sedangkan pada hasil model sesuai dengan daerah model oleh Chen, kecepatan arus mulai terbentuk pada jarak 140 meter dari batas model sebelah Timur dengan kecepatan arus maksimum yang terjadi adalah 0,58 $\mathrm{m} / \mathrm{s}$. 

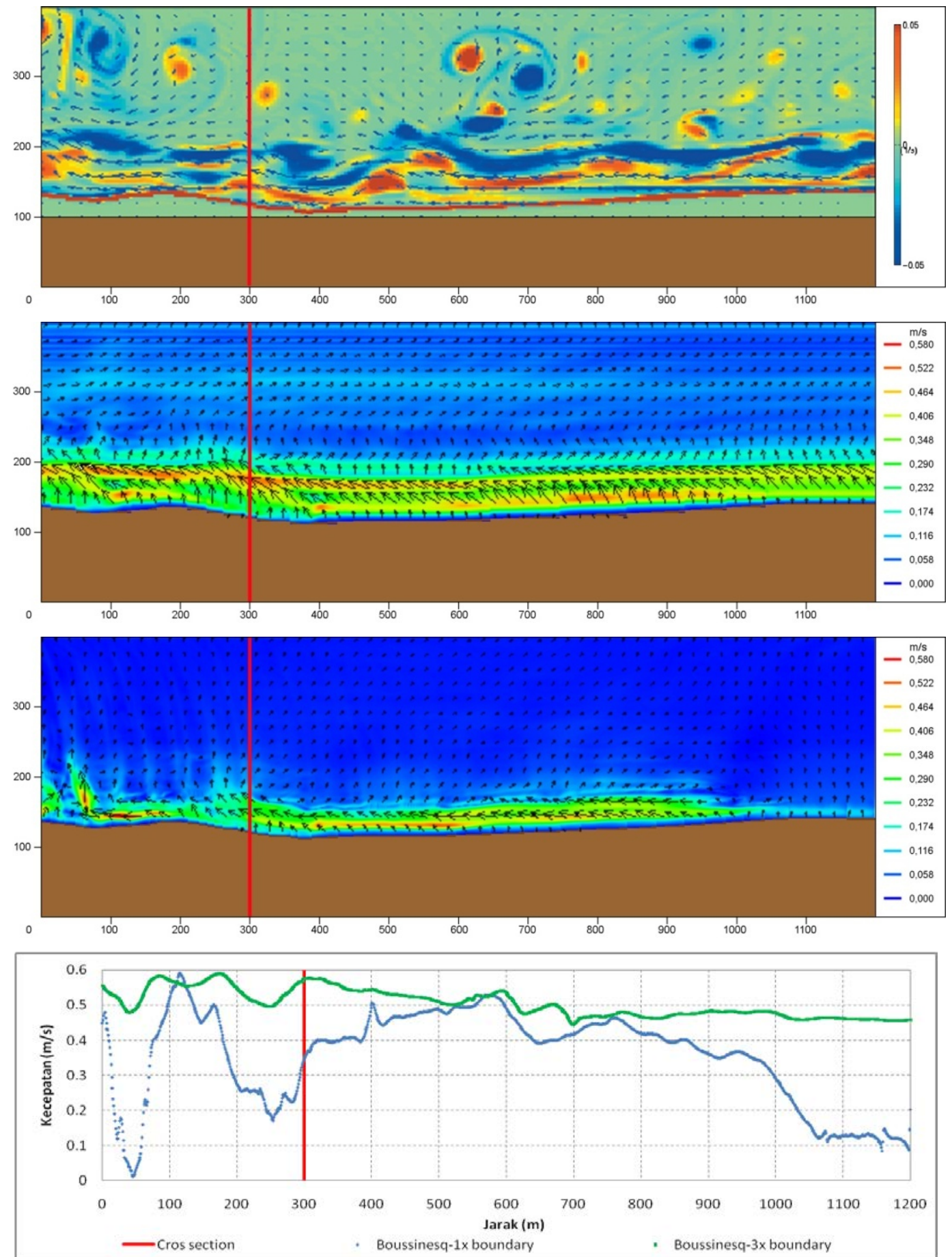

Gambar 4. Hasil model Boussinesq pada kondisi eksisting. (sumber : Chen., dkk 2003) 

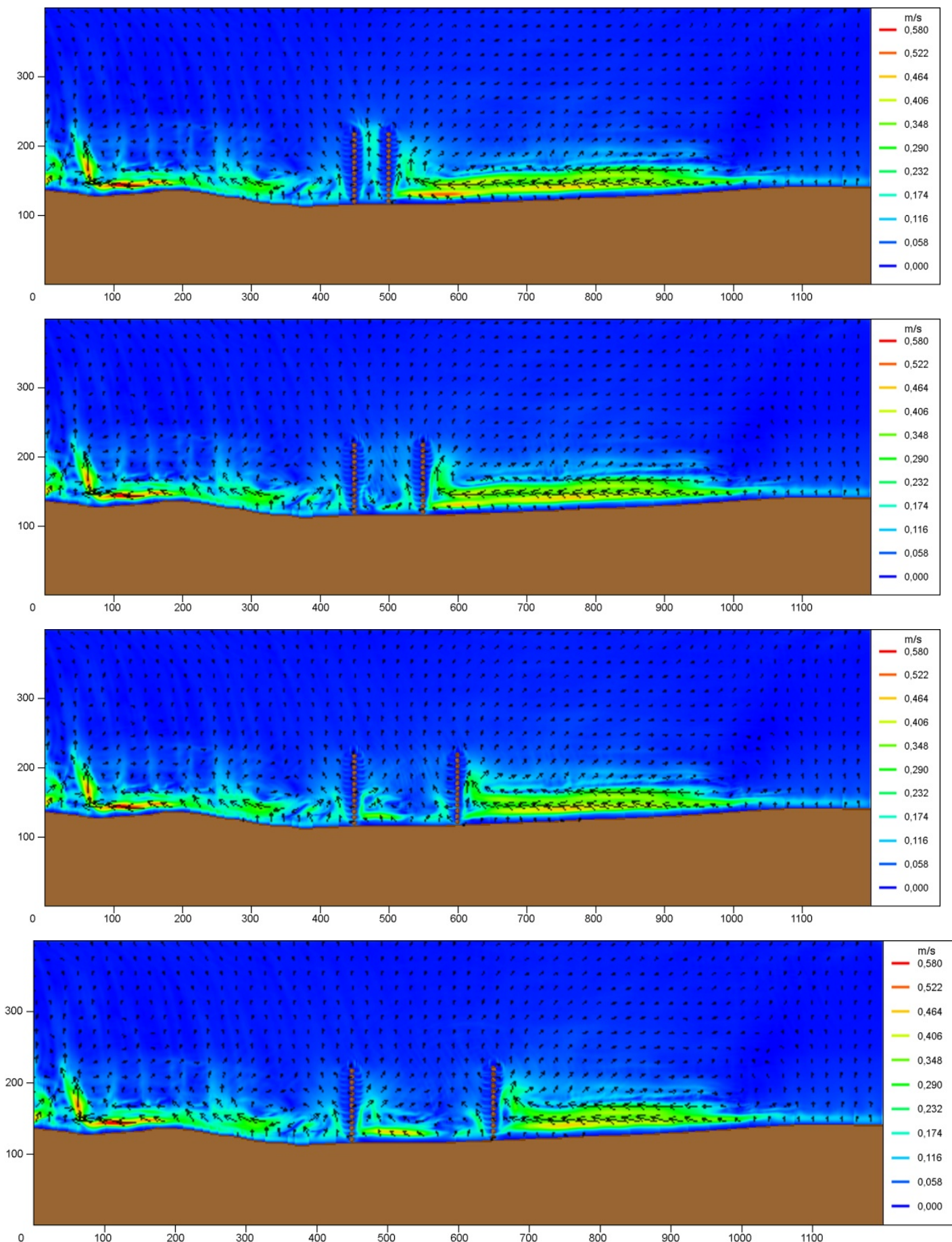

Gambar 5. Hasil model Boussinesq pada kondisi variasi jarak antar groin dan panjang groin tetap.

Gambar 5 menunjukkan hasil model kecepatan arus menyusur pantai dengan jarak antar groin 50 meter, 100 meter, 150 meter dan 200 meter. Hasil pemodelan menunjukkan bahwa jarak antar groin berpengaruh terhadap kecepatan arus menyusur pantai yang terjadi setelah struktur groin, dengan panjang groin yang tetap (L) dan semakin lebar jarak antar groin (B) atau B/L semakin besar maka reduksi kecepatan arus menyusur pantai oleh groin semakin kecil. 

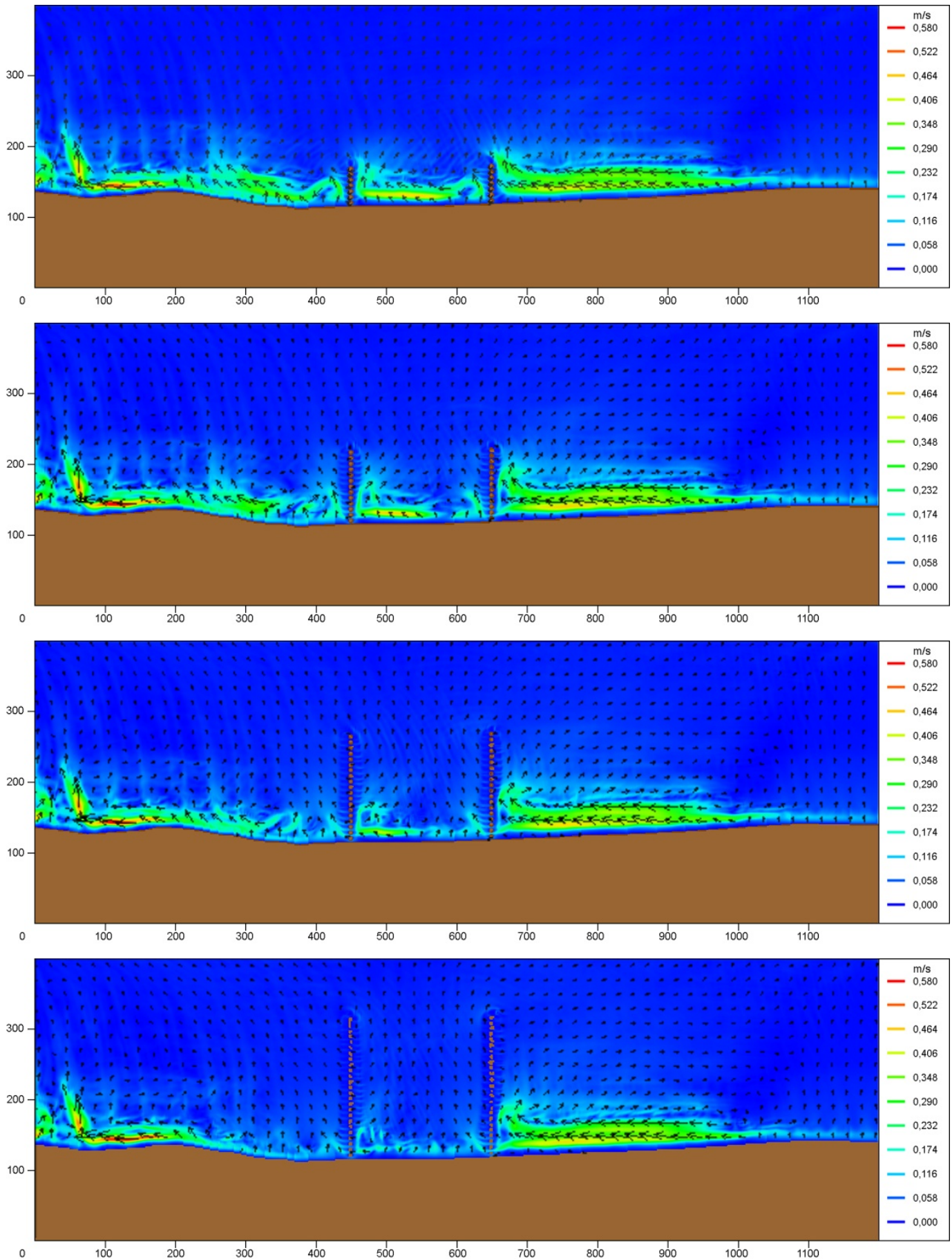

Gambar 6. Hasil model Boussinesq pada kondisi variasi panjang groin dan jarak antar groin tetap.

Gambar 6 berturut-turut dari atas ke bawah menunjukkan hasil model kecepatan arus menyusur pantai dengan panjang groin 50 meter, 100 meter, 150 meter dan 200 meter. Hasil model menunjukkan bahwa panjang groin berpengaruh terhadap kecepatan arus menyusur pantai yang terjadi setelah struktur groin, dengan jarak antar groin yang tetap (B) dan semakin panjang groin (L) atau B/L semakin kecil maka reduksi kecepatan arus menyusur pantai oleh groin semakin besar.

\section{Pengaruh groin permeable dan impermeable ganda terhadap arus menyusur pantai}

Hasil pemodelan untuk kondisi dengan groin permeable dan groin impermeable (Tabel 2) diperoleh hasil reduksi kecepatan arus menyusur pantai dengan rata-rata reduksi sebesar 59,21 \% untuk groin permeable ganda dengan panjang groin 50 meter, 76,02 \% untuk groin permeable ganda dengan panjang groin 100 
meter, 79,50 \% untuk groin permeable ganda dengan panjang groin 150 meter dan 80,49\% untuk groin permeable ganda dengan panjang groin 200 meter. Hasil pemodelan pada groin impermeable diperoleh hasil reduksi kecepatan arus menyusur pantai dengan rata-rata reduksi sebesar 57,42 \% untuk groin impermeable ganda dengan panjang groin 50 meter, 84,61 \% untuk groin impermeable ganda dengan panjang groin 100 meter, 88,89 \% untuk groin impermeable ganda dengan panjang groin 150 meter dan 89,91\% untuk groin impermeable ganda dengan panjang groin 200 meter.

Hasil model arus menyusur pantai dengan metode Boussinesq dengan variasi jarak antar groin dan variasi panjang groin diperoleh hasil bahwa semakin panjang groin permeable atau groin impermeable berpengaruh terhadap reduksi kecepatan arus menyusur pantai yang terjdi di daerah surf zone dengan penambahan reduksi kecepatan arus menyusur pantai yang terjadi sebesar $>20 \%$. Reduksi kecepatan arus menyusur pantai oleh groin permeable maupun groin impermeable tidak terjadi penambahan reduksi yang signifikan pada panjang groin dengan panjang melebihi daerah surf zone dengan rata-rata penambahan reduksi sebesar $>5 \%$. Hasil model arus menyusur pantai dengan variasi jarak antar groin diperoleh bahwa kecepatan arus menyusur pantai mendekati kecepatan arus menyusur pantai pada kondisi existing pada jarak $>2,4$ x panjang groin.

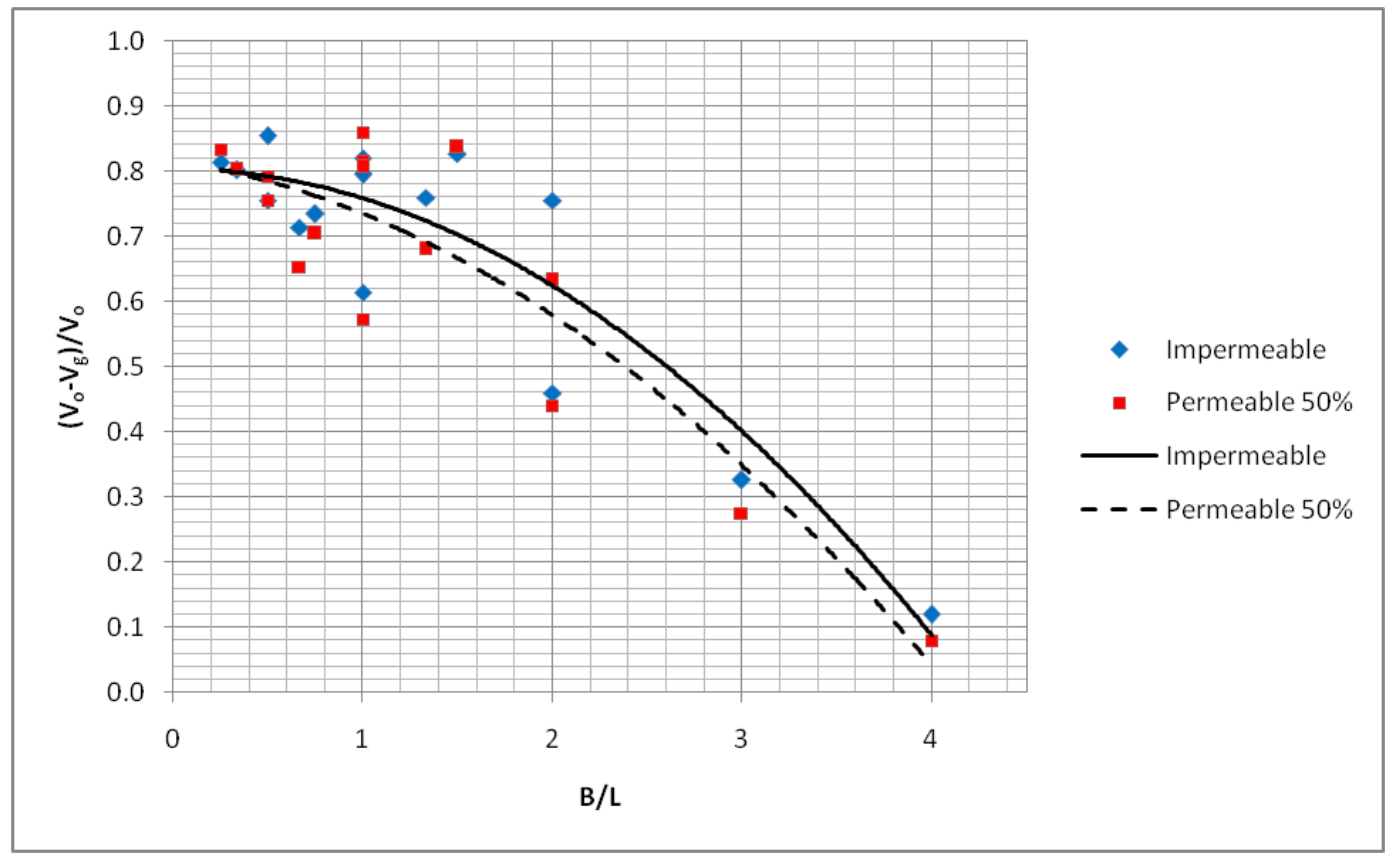

Gambar 7. Hubungan reduksi kecepatan arus menyusur pantai dengan variasi panjang dan jarak antar groin.

Hasil ekstrak data model arus menyusur pantai diketahui kecepatan rerata arus menyusur pantai sesudah adanya groin permeable dan groin impermeable. Ekstrak kecepatan arus menyusur pantai yang digunakan dalam pembuatan grafik analisa non dimensi ini dilakukan di tengah-tengah jarak antar groin (B) atau B/2. Besar reduksi kecepatan arus menyusur pantai karena adanya groin adalah selisih kecepatan arus tanpa groin $\left(\mathrm{V}_{\mathrm{o}}\right)$ dengan kecepatan arus setelah ada groin $\left(\mathrm{V}_{\mathrm{g}}\right)$ dibagi dengan kecepatan arus tanpa groin $\left(\mathrm{V}_{\mathrm{o}}\right)$. Gambar 7 menunjukkan profil kecepatan arus yang menggambarkan hubungan antara parameter non dimensi reduksi kecepatan arus dengan perbandingan panjang groin dengan jarak antar groin. Gambar 8 menunjukkan profil kecepatan arus yang menggambarkan hubungan antara parameter non dimensi koefisien reduksi kecepatan arus dengan perbandingan panjang groin dengan jarak antar groin.

Gambar 7 dan Gambar 8 menunjukkan bahwa permeabilitas groin berpengaruh terhadap reduksi kecepatan arus menyusur pantai, pada uji model dengan permeabilitas groin permeable $50 \%$ dan groin impermeable dapat dilihat bahwa reduksi arus menyusur pantai lebih besar pada uji groin impermeable dibandingkan dengan groin permeable 50\%. Hasil ini menunjukkan bahwa permeabilitas groin permeabel berpengaruh terhadap besar reduksi kecepatan arus menyusur pantai.

Hasil ekstrak data model arus menyusur pantai, diketahui kecepatan rerata arus menyusur pantai sesudah adanya groin permeable dan groin impermeable. Ekstrak kecepatan arus menyusur pantai yang digunakan dalam pembuatan grafik analisa non dimensi ini dilakukan ditengah-tengah jarak antar groin (B) atau B/2. Besar reduksi kecepatan arus menyusur pantai karena adanya groin adalah selisih kecepatan arus tanpa groin $\left(\mathrm{V}_{\mathrm{o}}\right)$ dengan kecepatan arus setelah ada groin $\left(\mathrm{V}_{\mathrm{g}}\right)$ dibagi dengan kecepatan arus tanpa groin $\left(\mathrm{V}_{\mathrm{o}}\right)$.

Gambar 7 menunjukkan profil kecepatan arus yang menggambarkan hubungan antara parameter non dimensi reduksi kecepatan arus dengan perbandingan panjang groin dengan jarak antar groin. Gambar 8 
menunjukkan profil kecepatan arus yang menggambarkan hubungan antara parameter non dimensi koefisien reduksi kecepatan arus dengan perbandingan panjang groin dengan jarak antar groin.

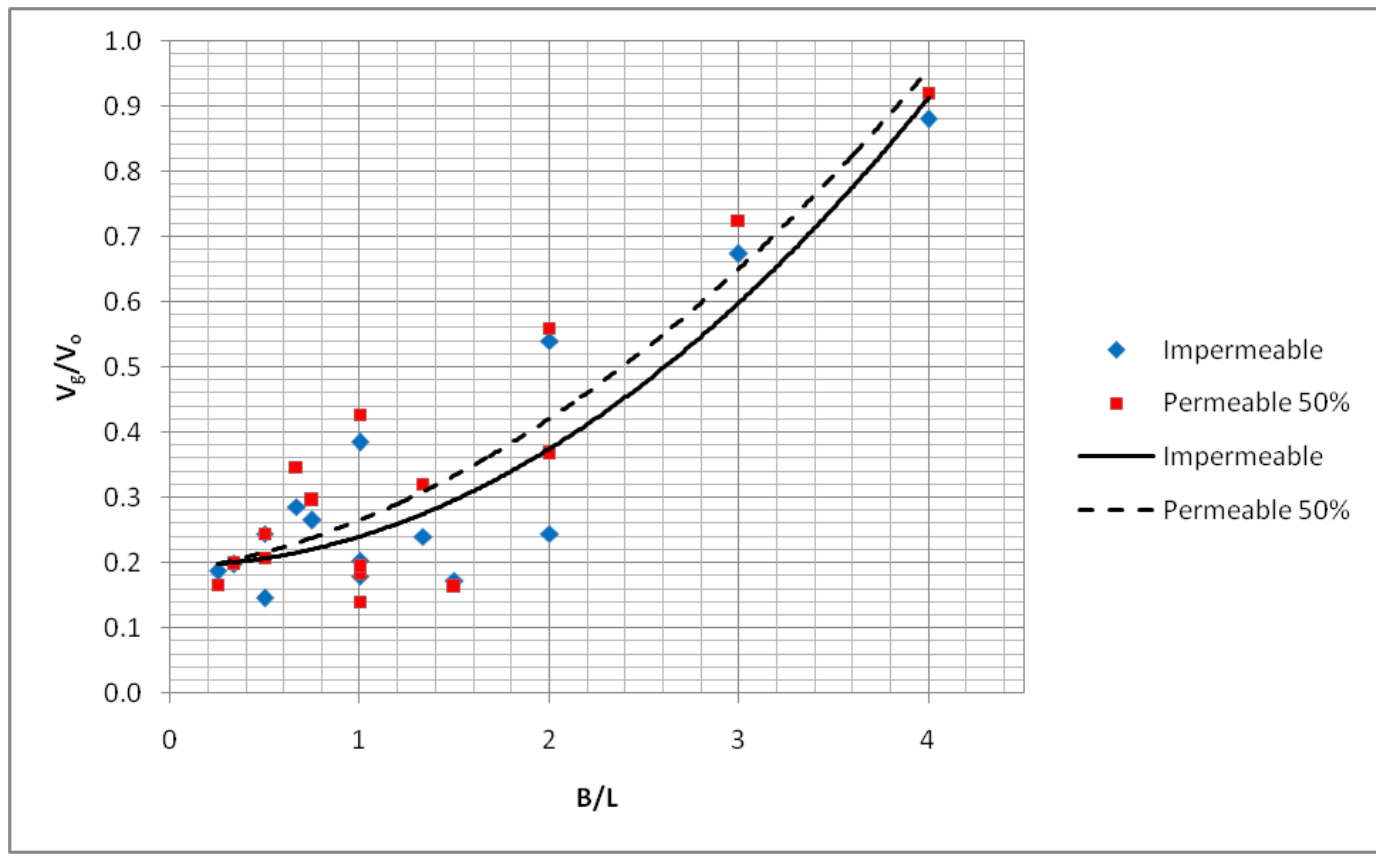

Gambar 8. Hubungan koefisien reduksi arus menyusur pantai dengan variasi panjang dan jarak antar groin.

Gambar 7 dan Gambar 8 menunjukkan bahwa permeabilitas groin berpengaruh terhadap reduksi kecepatan arus menyusur pantai, pada uji model dengan permeabilitas groin permeable $50 \%$ dan groin impermeable dapat dilihat bahwa reduksi arus menyusur pantai lebih besar pada uji groin impermeable dibandingkan dengan groin permeable 50\%. Hasil ini menunjukkan bahwa permeabilitas groin permeabel berpengaruh terhadap besar reduksi kecepatan arus menyusur pantai.

Gambar 8 dan Gambar 9 menunjukkan bahwa semakin besar nilai perbandingan jarak antar groin (B) dan panjang groin (L) maka nilai reduksi kecepatan arus semakin mengecil. Hasil ini menunjukkan bahwa jika perbandingan $(\mathrm{B} / \mathrm{L})$ terlalu besar maka kecepatan arus setelah groin mendekati kecepatan arus tanpa groin, dan sebaliknya jika perbandingan panjang dengan jarak antara groin semakin kecil maka reduksi kecepatan arus menyusur pantai semakin besar.

Tabel 2. Pengaruh groin Permeable dan Impermeable terhadap reduksi kecepatan arus menyusur pantai.

\begin{tabular}{clcccc} 
No. & Nama Model & \multicolumn{2}{c}{ Reduksi (\%) } & Reduksi 10 m setelah groin (\%) & Jarak reduksi minimum \\
& & Min-Max & Rata-rata & dari groin (m) \\
1 & EKSISTING & 0 & 0 & 53,06 & - \\
\hline 2 & P 50 L50 & $53,06-80,85$ & 64,21 & 65,91 & 10 \\
3 & P 50 L100 & $37,50-91,67$ & 63,05 & 65,38 & 80 \\
4 & P 50 L150 & $12,24-88,68$ & 45,32 & 52,50 & 100 \\
5 & P 50 L200 & $2,04-91,30$ & 31,92 & 71,43 & 120 \\
6 & P 100 L50 & $71,43-89,58$ & 81,84 & 75,51 & 10 \\
7 & P 100 L100 & $55,10-87,50$ & 72,96 & 84,62 & 30 \\
8 & P 100 L150 & $36,73-86,00$ & 66,06 & 72,50 & 110 \\
9 & P 100 L200 & $10,42-90,38$ & 48,98 & 77,55 & 140 \\
10 & P 150 L50 & $77,08-89,36$ & 81,83 & 77,55 & 40 \\
11 & P 150 L100 & $64,58-95,83$ & 75,69 & & 40
\end{tabular}




\begin{tabular}{lllllc}
12 & P 150 L150 & $67,35-91,67$ & 81,35 & 90,38 & 110 \\
13 & P 150 L200 & $34,69-87,76$ & 64,09 & 72,50 & 160 \\
14 & P 200 L50 & $79,59-91,49$ & 83,40 & 79,59 & 10 \\
15 & P 200 L100 & $72,92-91,67$ & 80,51 & 77,55 & 40 \\
16 & P 200 L150 & $61,22-95,83$ & 83,16 & 92,31 & 100 \\
17 & P 200 L200 & $61,22-90,57$ & 76,97 & 72,50 & 130 \\
18 & I 50 L50 & $51,02-82,98$ & 62,15 & 51,02 & 10 \\
19 & I 50 L100 & $33,33-89,58$ & 63,53 & 63,27 & 80 \\
20 & I 50 L150 & $10,20-94,34$ & 45,75 & 65,38 & 100 \\
21 & I 50 L200 & $2,04-88,64$ & 32,48 & 50,00 & 120 \\
22 & I 100 L50 & $77,08-89,36$ & 82,84 & 83,67 & 30 \\
23 & I 100 L100 & $48,98-87,50$ & 74,35 & 85,71 & 30 \\
24 & I 100 L150 & $29,17-88,00$ & 65,09 & 86,54 & 120 \\
25 & I 100 L200 & $10,20-92,31$ & 48,64 & 82,50 & 150 \\
26 & I 150 L50 & $77,08-91,49$ & 85,43 & 89,80 & 30 \\
27 & I 150 L100 & $56,25-93,75$ & 77,29 & 89,80 & 40 \\
28 & I 150 L150 & $68,00-95,83$ & 81,66 & 88,46 & 50 \\
29 & I 150 L200 & $33,33-90,57$ & 64,33 & 87,50 & 170 \\
30 & I 200 L50 & $81,25-93,62$ & 81,25 & 91,84 & 30 \\
31 & I 200 L100 & $75,51-89,80$ & 85,57 & 89,90 & 50 \\
32 & I 200 L150 & $59,18-91,67$ & 81,78 & 90,38 & 70 \\
33 & I 200 L200 & $57,14-93,88$ & 80,52 & 87,50 & 130 \\
\hline
\end{tabular}

\section{KESIMPULAN}

Pengujian model arus menyusur pantai yang dilakukan terhadap variasi panjang groin dan variasi jarak groin dengan groin Permeable dan Impermeable dapat diambil beberapa kesimpulan sebagai berikut.

1. Semakin besar nilai perbandingan jarak antar groin (B) dengan panjang groin (L) maka nilai reduksi kecepatan arus semakin mengecil, sebaliknya jika perbandingan panjang dengan jarak antara groin semakin kecil maka reduksi kecepatan arus menyusur pantai semakin besar.

2. Variasi jarak antar groin dan variasi panjang groin diperoleh hasil bahwa semakin panjang groin permeable atau groin impermeable berpengaruh terhadap reduksi kecepatan arus menyusur pantai. Kecepatan arus menyusur pantai setelah groin mendekati kecepatan arus menyusur pantai pada kondisi tanpa groin pada jarak $>2,4 \times$ panjang groin atau $\mathrm{B} / \mathrm{L}>2,4$.

Permeabilitas groin berpengaruh terhadap besar reduksi kecepatan arus menyusur pantai, semakin besar permeabilitas maka semakin kecil reduksi kecepatan arus menyusur pantai.

\section{DAFTAR PUSTAKA}

[1] Arab. S. E, 2009, A Numerical Study on Design of Normal and T-Head Groins, Delft University of Technology.

[2] Chen. Q., dkk, 2003, Boussinesq Modelling of Longshore Currents, Journal of Geophysical Research, University of South Alabama, USA.

[3] Emre. N. O, 1996, Shoreline Changes in The Vicinity of a Permeable Groin, Bogazici University, Turkey.

[4] Hasdinar Umar, 2012, Kajian Parameter Struktur Groin Permeable Tiang Untuk Pengendalian Arus Menyusur Pantai (Longshore Current), Desertasi UGM, Yogyakarta.

[5] Horikawa.K, 1988, Nearshore Dinamic and Coastal Process, University of Tokyo Press, Japan.

[6] Michael. T. Poff, dkk, 2004, Permeable Wood Groins: Case Study on their Impact on the Coastal System, Journal of Coastal Research, University of Florida, USA. 
[7] Pranata. ASP, 2013, Kajian Model Arus menyusur Pantai dengan Model Boussinesq wave pada Groin Permeable, Tesis, Universitas Gahdjah Mada, Yogyakarta.

[8] Sorensen. R. M, 2006, Basic Coastal Engineering, Springer, Lehigh University, Pennsylvania.

[9] Teraguchi. H, 2010, Morphological Changes Induced by River Training Structures: Bandal-like Structures and Groins, Kyoto University.

[10] Trampenau. T, dkk, 1996, Permeable Pile Groins, Journal of Waterway, Port, Coastal, and Ocean Engineering, ASCE.

[11] Trampenau. T, dkk, 2004, Functioning and Design of Coastal Groins, Journal of Coastal Research, University Braunschweig, Germany.

[12] Triatmodjo, B. 1999. Teknik Pantai. Beta Ofset. Yogyakarta.

Visser. R, 2002, Morphological Modelling in The Vicinity of Groynes, Delft University of Technology 